\title{
The Response of Some Rubber Seedling (Hevea brasiliensis) Clones on Various Types of Indigenous Mycorrhizae in Ex-Coal Mined Soil Media
}

\author{
Elis Kartika ${ }^{1 *}$, Lizawati Lizawati ${ }^{2}$, Made Deviani Duaja ${ }^{3}$, Gusniwati Gusniwati ${ }^{4}$ \\ ${ }^{1234}$ Department of Agroecotechnology Faculty of Agriculture University of Jambi \\ Jl. Raya Jambi - Muara Bulian KM 15, Mendalo Indah, Jambi, Indonesia \\ "Corresponding author.Email: elisk63@unja.ac.id
}

\begin{abstract}
The former coal mining activities caused marginal lands, which generally neglect land. Various activities are needed to rehabilitate the ground, especially technology that is effective and environmentally friendly. Mycorrhizae technology is an alternative strategy that should try and develop to optimize rubber plants' growth and development in the area. This experiment aims to get the best indigenous mycorrhizae types for each type of rubber clone in the ex-coal mining land as a planting media. This experiment is a two-factor factorial experiment using a Completely Randomized Design of three replications: The first factor, mycorrhizae isolate, consists of five levels: without AMF inoculation, Glomus sp-3, Glomus sp-6, Glomus sp-15, and Glomus sp-16 inoculation. The second factor, the type of rubber clone, consists of RRIM-300, GT-1, PB-260, and RRIC-100. The results showed an interaction between the typical isolate and rubber clones' styles in enhancing rubber seedlings in the leading nurseries. The best growth for RRIM-300 and GT-1 rubber clones in rubber seedlings which inoculated by Glomus sp-6, whereas in PB-260 and RRIC-100 clones in Glomus sp16.
\end{abstract}

Keywords: Rubber seedling, mycorrhizae, coal mining.

\section{INTRODUCTION}

Jambi Province is one of the production centers of a rubber plant in Indonesia. The rubber plantations area continues to increase, from 662.213 hectares in 2013 to 669.135 hectares in 2017. The production in 2013 is 323.271 to $1.123,329$ tons /ha in 2017. Likewise, the export volume increased from 198.149.000 tons in 2013 to 256104000 tons in 2017 [1]. That shows that the rubber plant is one of the leading regional commodities that have good prospects to develop in Jambi Province.

The main problem in smallholder rubber plantations in the production, only $929 \mathrm{~kg}$ of dry rubber/ha/year, is below the large estates, which averaged above $1000 \mathrm{~kg}$ of dry rubber/ha/year [1]. One of the reasons is that most of the plants are old, and rubber seedlings not recommend. Therefore it is necessary to replace old plants with rubber seedlings that recommend varieties (clones). Besides that also recommended expanding the rubber planting area to an unused space, which in Jambi Province is mostly ex-mining coal, gold and petroleum mining area. The characteristics of ex-mining land, in general, are open land, scorching, low fertility, easily eroded, potentially producing acid mine, drainage, and poor biodiversity. That causes the soil to be quickly submerged, deficient in nutrients, organic matter, and soil microorganisms. The ex-mining land is getting wider and unproductive. Reclamation of ex-mining land carries out to restore the ground following the initial conditions; later, it can use as agricultural.

The use of plants resistant to minimal conditions and soil fertility microbe's mycorrhizae is the right technology for land under minimal conditions. The rubber plant is a plant that has the potential to be used as a reclamation plant for ex-mining land. It has high adaptability and can live in the lowlands to a height of $700 \mathrm{~m}$ above sea level, from dry climates to rainfall reaching $3,000 \mathrm{~m} / \mathrm{year}$, from high-grade soils until the soil texture comes off. Rubber plants can provide organic material every year from falling leaves. Rubber has the property of aborting the leaves periodically once a year; besides falling leaves, the addition of organic matter also increases the number of microorganisms in the soil. The application of mycorrhizae technology is one of the 
potential alternative strategies that can help rubber plant growth and development on marginal lands.

According to Smith et al [2], Suharto and Sancayaningsih [3], Bano and Ashfaq[4], Gomes et al [5], Lateef et al [6], Kartika et al [7], Kartika et al [8], Evelin et al [9], and Gong and Tian [10], mycorrhizae is an alternative technology to help plant growth and development, especially those planted on marginal lands. That is due to mycorrhizal having various biological potentials, such as improving plant nutrition, bio-protection, increasing plant resistance to drought, engaging in bio-geo-chemical cycles. And synergizing with other microorganisms and being able to maintain plant diversity.

Each type of mycorrhizae's effectiveness depends on mycorrhizae's type and highly dependent on the plant, soil, and the interaction between those. Type of plant gives a different response to mycorrhizae; soil type has closely related to $\mathrm{pH}$ and soil fertility. Each mycorrhizae has a difference ability and effectiveness to increase nutrient uptake and plant growth ([11], [12], [13], [14], [15] and [16]).

This experiment aims to get the best indigenous mycorrhizae for each type of rubber clone in the ex-coal mining media.

\section{MATERIAL AND METHOD}

This experiment is a factorial experiment using a Completely Randomized Design. The first factor is mycorrhizae, which consist of five levels. Its levels consist of M0 (without mycorrhizal inoculation), $\mathrm{m} 1$ (Glomus sp-3 isolate inoculation), $\mathrm{m} 2$ (Glomus sp-6 isolate inoculation), $\mathrm{m} 3$ (Glomus $s p-15$ isolate inoculation), and $\mathrm{m} 4$ (Glomus sp-16 isolate inoculation). The second factor is rubber clone consists of four levels, k1 (RRIM-300 rubber clone), k2 (GT-1 rubber clone), k3 (PB-260 rubber clone), and k4 (RRIC-100 rubber clone). Thus, there are 20 treatment combinations obtained. Each treatment combination repeats three times so that there were 60 experimental units. Each unit experiment consisted of 4 polybags.

Propagation of inoculums carries out on indigenous mycorrhizal isolates from ex-coal mines obtained from Lubuk Mandarsyah Village, Tebo Regency at 1.289722, 102697110 [17]. These cultures will maintain in a greenhouse until approximately four months old during maintenance activities watering and administering a Red Hyponex nutrient solution (25-5-20) with a $1 \mathrm{~g} / 2 \mathrm{~L}$ of water concentration. Planting media is the soil from excoal mining land in Sungai Bengkal Village, Tebo Regency at $1.517403,102.736130$. It was drained and sieved with a ten mesh sieve and sterilized to kill all soil organisms. Only the inoculated mycorrhizae isolate develops and responds to isolate an application. Soil that uses as a media fix before being put into polybags.

The rubber seedlings clones used are three months old. Mycorrhizae injection performs by giving mycorrhizal inoculums on the growing media in each polybag with a dosage of $15 \mathrm{~g}$ per polybag. Observation of growth variables increases seedling height, stem diameter and number of leaves, shoot and root dry weight, $\mathrm{P}$ uptake, and root infection at seven months seedling old. The observational data were analyzed statistically using variance analysis and DMRT at $\alpha=$ $5 \%$.

\section{RESULTS AND DISCUSSION}

\subsection{RESULT}

\subsubsection{Seedling Height Increasing}

Increasing in the seedling height of various rubber clones and mycorrhizae isolates, shown in Figure 1.

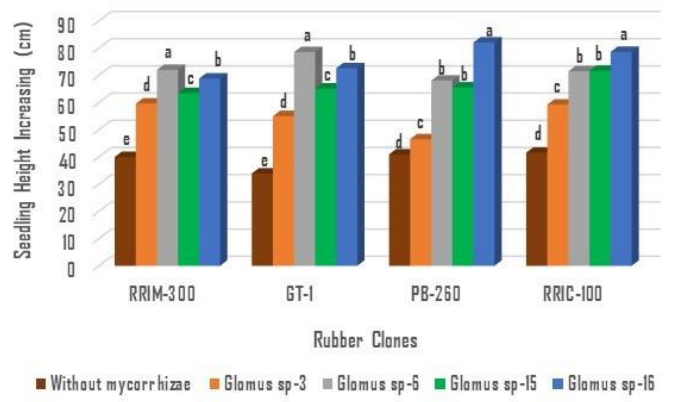

Figure 1. The average seedling height increases of various types of rubber clones and mycorrhizal isolates (bars followed by the identical lowercase are not significantly different according to DMRT at $\alpha=0.05$ ).

Figure 1 shows that the rubber clones inoculate with mycorrhizae increased significantly higher seedling height increasing than without mycorrhizae for all types of rubber clones. Furthermore, it indicates that the highest increase was achieved at clones RRIM-300 and GT-1 at Glomus sp-6, whereas clones PB-260 and RRIC100 rubber achieve at Glomus sp-16.

\subsubsection{Stem Diameter Increasing}

The average stem diameter increases at various rubber clones and different types of mycorrhizal isolates show in Figure 2. 


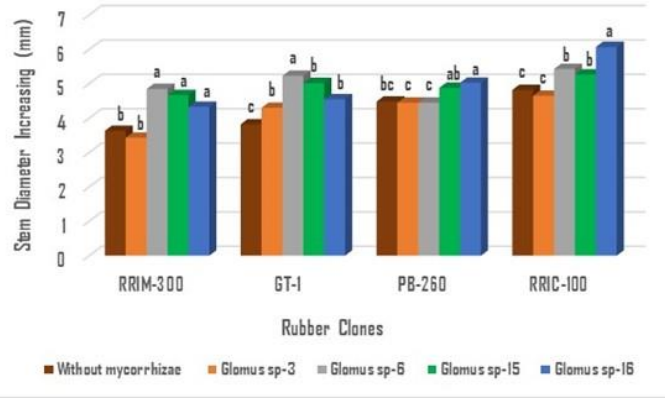

Figure 2. The average stem diameter increasing of various rubber clones $(\mathrm{mm})$ and multiple types of mycorrhizae isolate (bars followed by the identical lowercase are not significant according to DMRT at $\alpha=$ $0.05)$.

Figure 2 shows that inoculate rubber clones with mycorrhizae have a higher stem diameter than without mycorrhizae. It also shows that the highest stem diameter increases in clones RRIM-300, which inoculates with Glomus sp-6 but not significantly different with Glomus $s p-15$ and Glomus sp-16. For treatment rubber clones GT-1 the highest stem diameter increasing obtain in rubber clones inoculated with Glomus sp-6. For clones PB-260 and RRIC-100, the highest stem diameter increasing was achieved at Glomus sp-16.

\subsubsection{Leaf Number Increasing}

The average value of leaves number increases at various types of rubber clone and mycorrhizae isolates shown in Figure 3.

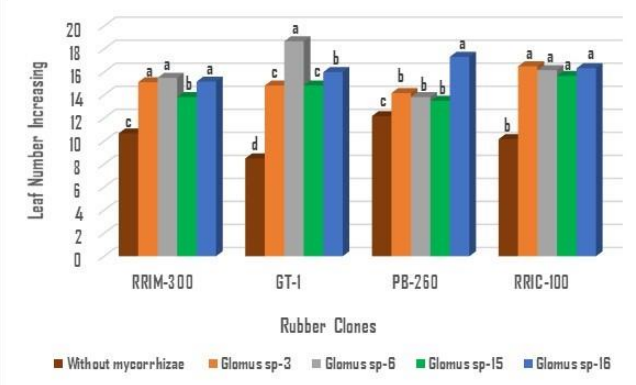

Figure 3. The average seedling leaves number increasing of various types of rubber clones and mycorrhizae isolates (bars followed by the same lower case are not significantly different according to DMRT at $\alpha=0.05$ ).

Figure 3 shows rubber seedlings that inoculate with mycorrhizae have a significantly higher number of leaves, increasing compared to without mycorrhizae for all types of rubber clones. Furthermore, the highest number of leaves increasing was achieved at clones RRIM-300 and inoculated with Glomus sp-6, not significantly different from Glomus sp-3 and Glomus $s p$ 16. And for clone GT-1, the highest obtain in Glomus sp-6. In clone PB-260, the highest number of leaves increasing achieve at the Glomus sp-16, and for clones,
RRIC-100 was conducted at Glomus sp-16 and not significantly different with Glomus $s p-3 s p-6$, and $s p-15$.

\subsubsection{Shoot Dry Weight}

The average shoots dry weight at various rubber clones and mycorrhizae isolates, shown in Figure 4.

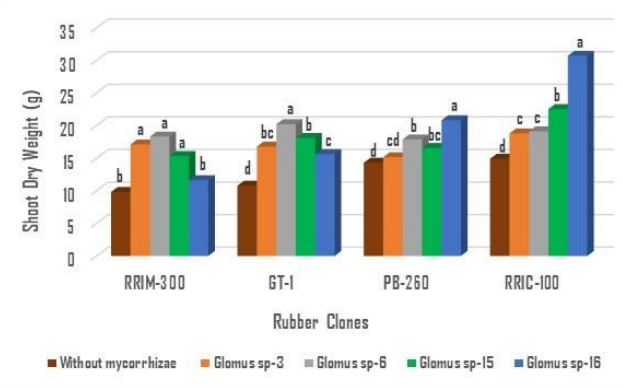

Figure 4. The average shoot dry weight at various types of mycorrhizae isolates and rubber clones. (bars followed by the identical lowercase are not significantly different according to DMRT at $\alpha=0.05$ ).

Figure 4 shows that rubber clones that inoculate with mycorrhizae have a significantly higher shoot dry weight than without mycorrhizae. The tallest plants dry weight at clones RRIM-300 was obtained on Glomus sp-6, but not substantially different from Glomus sp-3 and Glomus $s p-15$. For clones GT-1, the highest accept at Glomus sp6 and clones PB-260. At clones RRIC-100, the highest dry weight achieve at the Glomus sp-16.

\subsubsection{Root Dry Weight}

The average value of root dry weight at various rubber clones and mycorrhizae isolates shows in Figure 5.

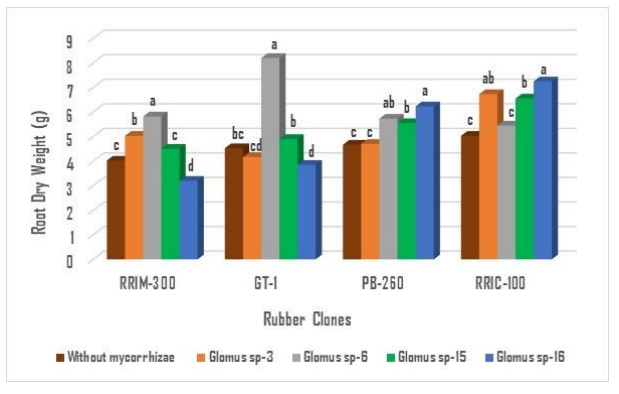

Figure 5. The average root dry weight at various types of mycorrhizae isolates and rubber clones (bars followed by the identical lowercase are not significantly different according to DMRT at $\alpha=0.05$ ).

Figure 5 shows rubber clones that inoculate with mycorrhizae have higher root dry weight than without mycorrhizae. The highest root dry weight of RRIM-300 and GT- 1 clone was obtained at Glomus sp-6, whereas in 
clones PB-260 and RRIC-100, the highest root dry weight was achieved Glomus sp-16.

\subsubsection{Phosphorus Uptake}

The value of Phosphorus uptake at various rubber clones and mycorrhizae isolates shows in Figure 6.

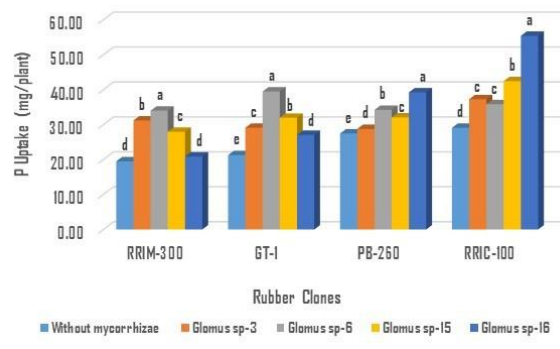

Figure 6. The average $\mathrm{P}$ uptake at various types of mycorrhizae isolates and rubber clones (bars followed by the identical lowercase are not significantly different according to DMRT at $\alpha=0.05$ ).

Based on Figure 6, it can see that rubber seedlings that inoculate with mycorrhizae have significantly higher $\mathrm{P}$ uptake than without mycorrhizae for all types of rubber clones. The most increased P uptake of clones RRIM-300 and GT-1 obtain in rubber clones inoculated with Glomus $s p-6$, while in clones PB-260 and RRIC-100, the highest $\mathrm{P}$ uptake achieve in Glomus sp-16.

\subsubsection{Root Infection}

The average value of root infection at various rubber clones and mycorrhizae isolates, shown in Figure 7.

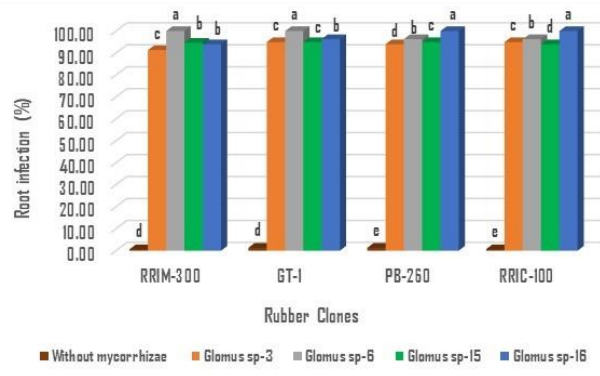

Figure 7. Average root infection of rubber seedlings at various types of mycorrhizae isolates and multiple types of rubber clones (bars followed by the identical lowercase are not significantly different according to DMRT at $\alpha=0.05)$.

Figure 7 shows that rubber clones RRIM-300 and GT1 obtain rubber seedlings in rubber seedlings, which inoculated with Glomus sp-6, whereas in clones PB-260 and RRIC-100, the highest root infection achieve in Glomus sp-16.

\section{DISCUSSION}

The results showed that the performance of growth and $\mathrm{P}$ uptake of various rubber clones and mycorrhizae isolates was higher than clones without mycorrhizae inoculated, demonstrated by all observed variables (Figure 1-7). That means rubber clones inoculated by mycorrhizae. It can grow and develop better than without mycorrhizae inoculated. The use of mycorrhizae is capable of increasing nutrients, both macro and micro. It can also absorb nutrients inbound and not available to plants like P. Mycorrhizae can associate with almost $90 \%$ of species plants and increase absorption efficiency of nutrients, especially $\mathrm{P}$ in marginal land [18].

$\mathrm{P}$ is bound and dissolved in the soil, but mycorrhizae release the phosphatase enzyme; this enzyme can release $\mathrm{P}$ bonds, that $\mathrm{P}$ becomes available in the ground and can absorb by the host plant. According to Octavianti and Ermavitalini [19], mycorrhizae play a role in increasing the absorption of soil nutrients needed by plants such as $\mathrm{P}, \mathrm{N}, \mathrm{K}, \mathrm{Zn}, \mathrm{Mg}, \mathrm{Cu}$, and $\mathrm{Ca}$. The effectiveness of host plants' effectiveness of nutrient uptake depends on complex interactions between soil capacity, plant nutrient requirements (phosphorus), the ability of fungi to infect and provide nutrients for host plants.

Furthermore, it can explain that mycorrhizae isolates can increase rubber seedlings' growth due to mycorrhizae with the enzyme phosphatase able to $\mathrm{P}$ free that was not available in the soil. The speed of plant growth is an indication of an efficient photosynthesis process. [20], showed mycorrhizae were able to increase growth, phosphatase enzyme activity, and $\mathrm{P}$ uptake of cocoa and coffee seedling. According to Ingraffia et al [21], mycorrhizae were also able to increase $\mathrm{P}$ and $\mathrm{N}$ uptake in corn plants.

According to Kartika [8], in the study of Jatropha, which plants in the ex-coal mining soil, with mycorrhizae inoculation and $\mathrm{P}$ fertilized with only $50 \%$ of the recommended dosage showed the best N, P, K uptake and the highest yield of Jatropha fruit. That is in line with the study results of Ingraffia et al [22], in wheat intercropping with faba bean, mycorrhizae inoculation, mycorrhizae can increase growth, uptake of P, fixation, and transfer of $\mathrm{N} 2$.

The working principle of this mycorrhizae is to infect the host plant's root system, producing hyphae intensively so that plants containing mycorrhiza will increase the capacity in nutrient absorption. This mycorrhiza can secrete enzymes of phosphatase and organic acids, especially oxalate, which can help free P. According to Varma et al [23], root infection starts from propagules (spores from root residues) or from roots adjacent to plants capable of infecting the roots of host plants because of the signal in the form of flavonoid 
exudates from the sources. Root infection is related to the formation of sugar exudates and organic acids. Mycorrhizae quickly convert and transfer photosynthetic results from host plants into specific carbon compounds as lipids or glycogen. Root colonization begins with the growth of hyphae from the three sources of inoculum (spores, hyphae, and root pathogens infected with mycorrhizae) will then develop and undergo primary colonization starting at a distance of $13 \mathrm{~mm}$. Infertile soils, the fungus development decreases so that the infection process also decreases, whereas conversely nutrient in poor soils increases the percentage of infections.

Each rubber seedling clone responds differently to various mycorrhizae types, as shown by all the observed variables (Figure 1-7). The highest growth and uptake of Phosphor at RRIM-300 and GT-1 rubber seedling clones were obtained at Glomus sp-6 inoculation, whereas PB260 and RRIC-100 rubber clones achieve at Glomus sp16 inoculation treatment.

The effectiveness of mycorrhizae in increasing plant growth and nutrient uptake determine by mycorrhizae types, plant genotypes, and soil conditions, and the interactions [24]. Each type of plant gives a different response to mycorrhizae. And each mycorrhiza has a difference in the ability to increase plant growth and nutrient absorption [25].

Based on this research, the result showed that each rubber clone's seedling responds differently to various types of mycorrhizae. Each rubber seedling clone has different types of mycorrhizae in promoting the best growth and uptake of $\mathrm{P}$. This shows that mycorrhizae have other efficiency and effectiveness to increase growth and nutrient uptake to different kinds of rubber clones. As some research showed, each type of mycorrhizae has additional efficiency and energy to improve plant growth, depend on mycorrhizae, host and soil type, and the interaction of it ([12], [26], [13], [16]).

The highest growth and P uptake of clones RRIM-300 and GT-1 were obtained at Glomus sp-6, whereas clones PB-260 and RRIC-100 were achieved at Glomus sp-16 inoculation treatment. This interaction shows that each type of isolate has a different effect on the host plant. Differences in effectiveness can occur between mycorrhizae types, which can cause by differences in hyphae growth in roots due to various root infections (Figure 7). As a result, the isolates' effectiveness in increasing nutrient absorb shows by the $\mathrm{P}$ absorption variable (Fig 6).

Following Bagyaraj [27], the differences in the effectiveness of mycorrhizae isolate types to increase nutrient absorption are influenced by the ability to increase the distribution of hyphae, the ability to form broad colonization, the efficiency of nutrient absorb especially phosphorus, and the time to nutrient transformation through hypha towards plants.

\section{CONCLUSION}

Based on the results of this research, the following conclusions:

1. There is an interaction between mycorrhizae types and rubber clones types in increasing rubber seedlings growth planted in ex-coal mine soil at the main nursery.

2. The best rubber seedling growth in ex-coal mining soils at rubber clones RRIM-300 and GT-1, which inoculated with Glomus sp-6, and in PB-260 and RRIC-100 clones, which inoculated with Glomus sp16.

\section{ACKNOWLEDGMENTS}

The authors appreciate the financial support from the Ministry of Research, Technology and Higher Education, Directorate General of Research Strengthening and Development

\section{REFERENCES}

[1] Directorate General of Estate Crops, Tree Crop Estate Statistics of Indonesia-Rubber. Secretariate of Directorate General of Estates, Directorate General of Estates. Ministry of Agriculture. 2019.

[2] S. E. Smith, E. Facelli, S. Pope, and F. A. Smith, "Plant performance in stressful environments: interpreting new and established knowledge of the roles of arbuscular mycorrhizas," Plant Soil, vol. 326, no. 1, pp. 3-20, 2010.

[3] S. Suharto and R. P. Sancayaningsih, "Arbuscular Mycorrhizae Fungi: The potential use of heavy metal mycorrhizo-remediation technology in mined field rehabilitation," Bioteknologi, vol. 10, no. 1, pp. 23-34, 2013.

[4] S. A. Bano and D. Ashfaq, "Role of mycorrhiza to reduce heavy metal stress," Nat. Sci., vol. 05, no. 12, pp. 16-20, 2013.

[5] M. P. Gomes, M. L. Andrade, C. C. Nascentes, and M. R. Scotti, "Arsenic root sequestration by a tropical woody legume as affected by arbuscular mycorrhizal fungi and organic matter: Implications for land reclamation," Water. Air. Soil Pollut., vol. 225, no. 4, 2014. 
[6] A. A. H. A. Lateef et al., "Arbuscular mycorrhizal symbiosis and abiotic stress in plants: A review," J. Plant Biol., vol. 59, no. 5, pp. 407-426, 2016.

[7] E. Kartika, M. D. Duaja, and G. Gusniwati, "The Growth of Immature Oil Palm Plant (Phase 1) to Indigenous Mycorrhizal and Organic Fertilizer Doses Application on Marginal Land," Biospecies Vol. 9 No.1, January 2016, hal 2937., vol. 9, no. 1, 2016.

[8] E. Kartika, L. Lizawati, and H. Hamzah, "Jatropha curcas L. Responses to Indigenous Mycorrhizae and P Fertilizers at Coal PostMining Land," Biospecies Vol. 11 No. 1, January 2018, vol. 11, no. 1, pp. 10-18, 2018.

[9] H. Evelin, T. S. Devi, S. Gupta, and R. Kapoor, "Mitigation of salinity stress in plants by arbuscular mycorrhizal symbiosis: Current understanding and new challenges," Frontiers in Plant Science, vol. 10. 2019.

[10] X. Gong and D. Q. Tian, "Study on the effect mechanism of Arbuscular Mycorrhiza on the absorption of heavy metal elements in soil by plants," IOP Conf. Ser. Earth Environ. Sci., vol. 267, no. 5, 2019.

[11] M. Muzakkir, E. F. Husin, A. Agustian, and A. Syarif, "Efektivitas Berbagai Fungi Mikoriza Arbuskular Indigenus terhadap Serapan Hara P dan Pertumbuhan Tanaman Jarak Pagar (Jatropha curcas L.)," J. Solum, vol. 7, no. 2, p. $137,2010$.

[12] M. Thorne, L. Rhodes, and J. Cardina, "Effectivity of arbuscular mycorrhizal fungi collected from reclaimed mine soil and tallgrass prairie," Open J. Ecol., vol. 03, no. 03, pp. 224233,2013

[13] P. R. O. Purba, N. Rahmawati, E. H. Kardhinata, and A. Sahar, "The effectivity of some type Arbuscular Mycorrhizal Fungi on rubber (Hevea brassiliensis Muell. Arg.) growth in seedlings," $J$. Agroekoteknologi Univ. Sumatera Utara, vol. 2, no. 2, pp. 919-932, 2014.

[14] R. Hamida and K. Dewi, "Effectiveness of Vesicular Arbuscular Mycorrhiza and 5Aminolevulinic Acid on the Growth of Local Madura Variety Maize to Drought Stress.," pp. 61-67, 2014.

[15] N. Tahir, N. Sennang, A. Ala, Kaimudin, and Nasaruddin, "Original Research Article The Effectivity of Arbuscular Mycorrhizal Utilization and The Level of Watering Toward The Growth and Production of Soybean Plants,"
International J. Curr. Microbiol. Appl. Sci., vol. 4, no. 5, pp. 928-937, 2015.

[16] G. A. E Silva, J. O. Siqueira, S. L. Stürmer, and F. M. de S. Moreira, "Effectiveness of arbuscular mycorrhizal fungal isolates from the land uses of Amazon region in symbiosis with cowpea," Ann. Acad. Bras. Cienc., vol. 90, no. 1, pp. 357-371, 2018 .

[17] E. Kartika, L. Lizawati, and H. Hamzah, "Isolation, Identification, and Purification of Arbuscular Mycorrhiza Fungi (AMF) from Coal Post Mining Soil," vol. 1, no. 4, pp. 225-235, 2012.

[18] A. H. Simanungkalit, S. H. Asmarlaili, and T. Sabrina, "The Potential Test of Vesicular Arbuscular Mycorrhiza (VAM) on The Growth of Maize (Zea mays L.) on Inceptisol Soil Astri," J. Chem. Inf. Model., vol. 53, no. 9, pp. 1689$1699,2017$.

[19] E. N. Octavianti and D. Ermavitalini, "Identifikasi Mikoriza dari Lahan Desa Poteran, Pulau Poteran, Sumenep Madura," J. Sains POMITS, vol. 3, no. 2, pp. 53-57, 2014.

[20] A. Suparno, S. Prabawardani, S. Yahya, and N. A. Taroreh, "Inoculation of Arbuscular Mycorrhizal Fungi Increase the Growth of Cocoa and Coffee Seedling Applied with Ayamaru Phosphate Rock," J. Agric. Sci., vol. 7, no. 5, 2015.

[21] A. Diouf, M. Ndiaye, M. A. Fall-Ndiaye, and T. A. Diop, "Maize Crop N Uptake from Organic Material of \&lt;i\&gt; Gliricidia sepium \&lt;/i\&gt; Coinoculated with \&lt;i\&gt; Rhizobium\&lt;/i\&gt; and Arbuscular Mycorrhizal Fungus in Sub-Saharian Africa Sandy Soil," Am. J. Plant Sci., vol. 08, no. 03, pp. 428-440, 2017.

[22] R. Ingraffia, G. Amato, A. S. Frenda, and D. Giambalvo, "Impacts of arbuscular mycorrhizal fungi on nutrient uptake, $\mathrm{N} 2$ fixation, $\mathrm{N}$ transfer, and growth in a wheat/faba bean intercropping system," PLoS One, vol. 14, no. 3, pp. 1-16, 2019

[23] A. Varma, R. Prasad, and Narendra_Tuteja, Mycorrhiza - Nutrient Uptake, Biocontrol, Eco restoration. Springer. 2018

[24] M. Brundrett, N. Bougher, B. Dell, T. Grove, and N. Malajczuk, "Examining mycorrhizal associations," Work. with Mycorrhizas For. Agric., no. June 1982, pp. 173-193, 1996.

[25] B. . Daniels and J. . Menge, "Evaluation of the 
Commercial Potential of the VesicularArbuscular Mycorrhizal Fungus, Glomus Epigaeus," New Phytol., vol. 87, no. 2, pp. 345354, 1981.

[26] G. Wulandari, S. Suwirmen, and Z. A. Noli, "Compatibility of Glomus Spores Isolated From The Rhizosphere of Macaranga triloba with Three Types of Host Plants," J. Biol. Univ. Andalas, vol. 3, no. April, pp. 116-122, 2014.

[27] D.J.Bagyaraj, "Vesicular-arbuscular Mycorrhiza: Application in Agriculture," Methods Microbiol., vol. 24, no. C, pp. 359-373, 1992. 